\title{
Direct Shear Strength of RPC Member
}

\author{
Shahad Q. Madhlom ${ }^{a^{*}}$, Hussein A. Aziz ${ }^{b}$, Ammar A. Ali ${ }^{c}$ \\ ${ }^{\text {a }}$ University of Technology, Baghdad, Iraq. shahadqassim.sq@gmail.com \\ ${ }^{\text {b }}$ University of Technology, Baghdad, Iraq. 40133@uotechnology.edu.iq \\ ${ }^{\mathrm{c}}$ University of Technology, Baghdad, Iraq. 40046@uotechnology.edu.iq \\ ${ }^{*}$ Corresponding author.
}

Submitted: $12 / 03 / 2020$

Accepted: 08/05/2020

Published: 25/1/2021

K E Y W O R D S

Reactive powder concrete, Shear stress, Steel fiber

\begin{abstract}
A B S T R A C T
In this research paper, results are obtained from Reactive Powder Concrete (RPC) push-off specimens - double L shape subjected to direct shear loading. Different parameters considered are compressive strength, percentages of steel fiber, presence of aggregate and shear reinforcement. The results show that increasing in steel fiber content starting from $0.0 \%$ and ending with $1.5 \%$ leads to increases in the shear strength by (261\%) and attempt to decrease its brittleness. The presence of steel fiber content enhances and improves the tensile strength and the shear strength. Using $R P C$ in constructing the specimens enhances the shear strength by $29.6 \%$ compared with NSC specimen.
\end{abstract}

Shear strength increased by $25 \%$ when the compressive strength increased from 75 to 90MPa. The presence of transverse steel rebar in the direction of shear line increased the shear strength by (108.3\%) as compare with the specimen without shear rebar. The presence of small aggregate in RPC mix creates an increase in the shear strength by (9.1\%).

\footnotetext{
How to cite this article: S. Q. Madhlom, H. A. Aziz and A. A. Ali, "Direct Shear Strength of RPC Member," Engineering and Technology Journal, Vol. 39, Part A, No. 01, pp. 22-33, 2021.

DOI: https://doi.org/10.30684/etj.v39i1A.1638

This is an open access article under the CC BY 4.0 license http://creativecommons.org/licenses/by/4.0
}

\section{INTRODUCTION}

Reactive Powder Concrete (RPC) has different attributes such as the high strength of concrete against low level of porosity material while preserving high contents of cement, silica fume and fibers of macro steel. A new generation of super plasticizer combining by eliminating the coarse aggregates are used with low ratios of water-cement to produce RPC, which should combine by preserving optimized particle size under the 600 limits.

Different structural applications use RPC such as conditions where the concrete must resist stresses of essential tensile resulting from forces of shear or explosion. In addition, it is used when reducing the cross-sectional area, reduce cracks or increase the full-strength capacity of structural 
members such as slabs, columns, and shear walls by enhancing the mechanical attributes of the needed mix.

Concrete shear strength can be defined as one-layer resistance considering the other ones while slipping at common surface of contact. The most unwanted failure is the shear failure regarding the case when it suddenly progress. Many effective ways of designing the reinforced concrete members were studied due to this rapid type of failure [1]. A compromise between ductility and strength could be gained by utilizing discontinuous fibers. Increasing fibers in the concrete provides an isotropic and a homogenous material, whereas its brittle properties becomes ductile one $[1,2,3]$. At the time of concrete cracking, the role of fibers which are randomly oriented concerns with arresting micro cracking. Therefore, enhancing the strength of first-crack shear increases significantly the improvements in ultimate shear strength. Increasing the number of fibers affect the increasing portion of the stress-strain curve with slight differences against noticeable rise in the peak strain and a noticeable rise in ductility.

Ghailan [4], investigated the influences of RPC on the shear strength of concrete member. Total of (24) specimens were tested including (12) RPC and another (12) modified RPC subjected to predominantly in shear. The test and analytical results of RPC and modified RPC compared with normal concrete showed a great significant in shear strength capacity.

Hannawayya [5], investigated the mechanical properties such as compressive strength, splitting tensile strength, modulus of rupture (flexural test) and also the full behavior of stress - strain of RPC in addition to study the flexural behavior of RPC beams. The author considered different parameters like silica fume and fiber steel ratio. Based on test results, the main conclusions are that compressive strength increased by using increased ratio of fiber steel and silica fume.

Danha [6], studied the tensile strength of RPC with different percentages of steel fiber up to $(3 \%)$ and silica fumes up to (30\%). Using statistical analysis, the experimental results are modeled mathematically. Experimental results illustrated that the additives material improved the mechanical properties of concrete.

The main subjective of the present study is utilizing the push-off specimen to investigate the direct shear strength of RPC member. The variables considered are; steel fiber content, compressive strength of RPC, shear reinforcement ratio and presence of small size of aggregate in RPC mixture. The load-slip relations and load-crack width relations and modes of failure were presented in this study.

\section{PUSH-OFF TEST SPECIMENS}

Reinforced concrete push-off specimen details is shown in Figure (1). Table I lists the entire specimen dimensions. Eight reinforced concrete double inverted L shape were tested under direct shear static loading.

The push-off specimen details are presented in Figure 1. The mold is placed in stable position and then the reinforcement is fixed inside the mold. The concrete then is casted and vibrated with three layers to get homogenous mixing.

All double inverted $\mathrm{L}$ shape specimens are tested under direct shear static load up to failure. Test for reinforced concrete double inverted L shape specimens with concrete compressive strength that classified as groups in Table II are tested under direct shear static loading. The specimen rest at the middle of testing machine and two dial gauges were fixed to measure the vertical and lateral displacements with each load increment. The load was added gradually at the top center of the samples by means of hydraulic load cell. The test carried out with flexural test machine capacity $(2000 \mathrm{kN})$.

TABLE I: Specimen dimensions

\begin{tabular}{cccc}
\hline \hline Specimen & $\mathbf{L}(\mathbf{m})$ & $\mathbf{h}(\mathbf{m})$ & $\mathbf{b}(\mathbf{m})$ \\
\hline All & 0.3 & 0.64 & 0.15 \\
\hline
\end{tabular}



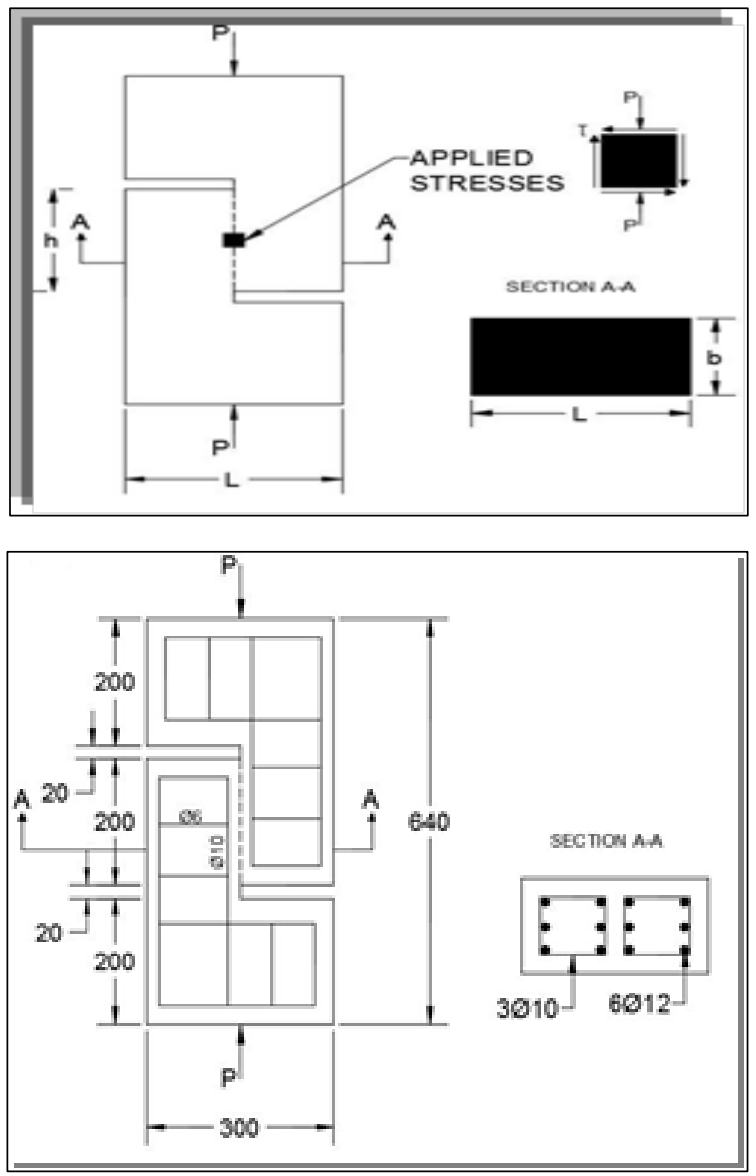

Figure 1: Specimen's details

\section{MATERIALS PROPERTIES AND MIX PROPORTIONS}

The mix proportion of the material used for constructed the RPC and NSC are presented in Table II. The ordinary Portland cement, quartz sand, steel fiber and super stabilizer (Glenuim 54) were used in constructed the RPC.

TABLE II: Mixes proportions of RPC

\begin{tabular}{|c|c|c|c|c|c|c|c|}
\hline $\begin{array}{l}\text { Specimen } \\
\text { mark }\end{array}$ & $\begin{array}{l}\text { Cement } \\
(\mathrm{kg} / \mathrm{m} 3)\end{array}$ & $\begin{array}{c}\text { Silica } \\
\text { fume }(\mathrm{kg} / \mathrm{m} 3)\end{array}$ & $\begin{array}{c}\text { Quartz sand } \\
(\mathrm{kg} / \mathrm{m} 3)\end{array}$ & $\begin{array}{c}\text { Super - } \\
\text { plasticizer } \\
(\mathrm{kg} / \mathrm{m} 3)\end{array}$ & $\begin{array}{c}\text { Steel } \\
\text { fiber } \\
(\mathrm{kg} / \mathrm{m} 3)\end{array}$ & $\begin{array}{c}\text { Water } \\
(\mathrm{kg} / \mathrm{m} 3)\end{array}$ & $\begin{array}{r}\text { Gravel } \\
(\mathrm{kg} / \mathrm{m} 3)\end{array}$ \\
\hline L1-REF & 45.13 & 11.22 & 56.34 & 1.40 & 2.0 & 9.77 & --- \\
\hline L3-FC80 & 45.13 & 11.22 & 56.34 & 1.40 & 2.0 & 7.55 & --- \\
\hline L4- $0 \%$ Fib & 45.13 & 11.22 & 56.34 & 1.40 & 0 & 7.55 & --- \\
\hline L5-1\%Fib & 45.13 & 11.22 & 56.34 & 1.40 & 4.0 & 7.55 & \\
\hline L8-AGG5mm & 45.13 & 11.22 & 37.56 & 1.40 & 2.0 & 7.55 & 18.77 \\
\hline L6-1.5\%Fib & 45.13 & 11.22 & 56.34 & 1.40 & 6.0 & 7.55 & \\
\hline L7-Rein & 45.13 & 11.22 & 56.34 & 1.40 & 2.0 & 7.55 & \\
\hline
\end{tabular}

Physical and chemical properties of the ordinary cement are according to the Iraqi specifications [7]. Ordinary water that mixed with other concrete components was used without any additives.

Reinforcements for double inverted L Shape concrete sections, different diameters are use such as $(\phi 12$ and $10 \mathrm{~mm})$ in diameter to reinforce the specimens. The mechanical properties and geometry lists in Table III. 
TABLE III: $\quad$ Mechanical properties of steel bars

\begin{tabular}{cccccc}
\hline \hline $\begin{array}{c}\text { Nominal bar } \\
\text { diameter } \\
(\mathrm{mm})\end{array}$ & $\begin{array}{c}\text { Actual bar } \\
\text { diameter } \\
(\mathrm{mm})\end{array}$ & $\begin{array}{c}\text { Modulus of } \\
\text { Elasticity } \\
(\mathrm{MPa})\end{array}$ & $\begin{array}{c}\text { Yield Stress } \\
(\mathrm{MPa})\end{array}$ & \%Elongation & $\begin{array}{c}\text { Ultimate } \\
\text { Stress }(\mathrm{MPa})\end{array}$ \\
\hline $\mathbf{1 0}$ & 9.98 & 204700 & 560 & 10 & 634 \\
$\mathbf{1 2}$ & 11.97 & 206000 & 540 & 16 & 635 \\
\hline
\end{tabular}

Four ratios of steel fibers $(0,0.5,1$ and $1.5 \%)$ respectively were used to investigate the effects of the presence of the behavior of steel fibers besides strength of RPC reinforced concrete double inverted L shape. The mechanical properties of the tested specimens are presented in Table IV.

TABLE IV:Mechanical properties of tested specimens

\begin{tabular}{ccccc}
\hline \hline Specimen & Type of concrete & \% Steel fiber & $\boldsymbol{f}_{\boldsymbol{c u}}(\mathbf{M P a})$ & $\boldsymbol{f}_{\boldsymbol{t}}(\mathbf{M P a})$ \\
\hline L2-NSC & NC & ---- & 35 & 2.7 \\
L1-Ref & RPC & 0.5 & 90 & 4.0 \\
L3-Fc80 & RPC & 0.5 & 75 & 3.2 \\
L4-0\%Fib & RPC & 0 & 87 & 1.8 \\
L5-1\%Fib & RPC & 1.0 & 98 & 5.0 \\
L6-1.5\%Fib & RPC & 1.5 & 105 & 6.5 \\
L7-Rein & RPC & 0.5 & 90 & 4.0 \\
L8-Agg5mm & RPC & 0.5 & 93 & 4.1 \\
\hline
\end{tabular}

All specimens are cured in a fresh-water container and kept the specimens up to the required time for tests. Table V presented the mix proportions of the material used in constructed the NSC.

TABLE V: Mix proportionality of NC

\begin{tabular}{cc}
\hline \hline Material & Weight $\left(\mathbf{k g} / \mathbf{m}^{\mathbf{3}}\right)$ \\
\hline Cement & 19.12 \\
Gravel & 52.5 \\
Sand & 33.6 \\
Water & 8.6 \\
Water/Cement & 0.45 \\
\hline
\end{tabular}

\section{EXPERIMENTAL PROGRAM}

The research was done in the laboratories of The University of Technology in the building and construction department. The practical program classified as materials and structural tests. Three tests for each type of concrete mechanical properties such as compressive strength and splitting tensile strength to ensure that the accurate of tests and mixes design. The reinforced concrete double inverted L shape specimens were tested under direct shear direct shear static loading until the specimen fail.

A total of eight push-off specimens were tested. The influence of steel fiber content on the shear strength was studied on three specimens (L1-Ref, L2-fib0\%, L5-1\%Fib and L6-1.5\%Fib). The effect of compressive strength of RPC was studied by comparing the specimens (L1-Ref, L3-Fc80, and L2NSC). The influence of shear reinforcement on the shear strength of RPC was investigated on two specimens ( L1-Ref and L7-Rein). Finally, the effect of presence of small size of aggregate in RPC mixed was studied on two specimens (L1-Ref and Agg5mm).

\section{MEASUREMENTS}

An accurately calibrated load cell was utilized to measure the subjected compression force. Dial gage (1) was putted at bottom of the sample to measure the relative motion (shear crack slip (s)) in between two push- off samples regarding the L blocks. The two dial gauges ( 2 and 3 ) were fixed at the start of a middle-third length of the shear plane and its end to measure the shear crack opening. 


\section{TEST SETUP}

All double inverted (L) shape specimens are tested under direct shear direct shear static load up to failure. Test for reinforced concrete double inverted (L) shape specimens with concrete compressive strength that classified as groups in Table III. Tested under direct shear direct shear static loading in which first the specimen rest at the middle of testing machine and two dial gages were fixed to measure the vertical and lateral displacements with each load increment. The load was added gradually at the top center of the samples by means of hydraulic load cell. The test carried out with flexural testing machine with capacity of $2000 \mathrm{kN}$.

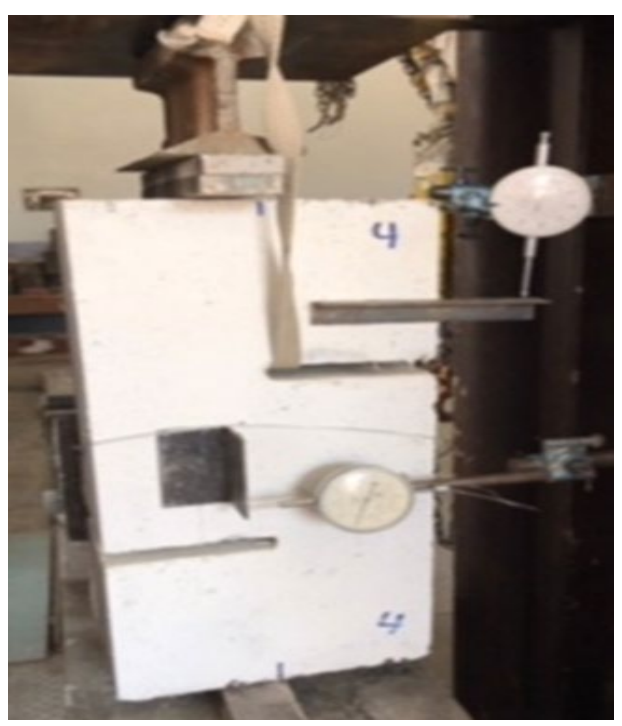

Figure 2: Specimen setup

\section{TEST RESULTS AND DISCUSSION}

\section{Ultimate shear strength}

The ultimate shear strength of RPC is calculated according to the equation:

$$
\tau_{\max }=\mathrm{P}_{\max } /(\text { b.L })
$$

Where: $\tau$ is the shear strength of RPC; $\mathrm{P}_{\max }$ is the maximum applied load; $\mathrm{b}$ is the specimen width and $\mathrm{L}$ is the distance of the connected area between two $\mathrm{L}$ angle.

Table VI illustrated the values of the shear strength for tested specimens, in which:

1) Using RPC in constructing the specimens increased the shear strength by $29.6 \%$ compared with NSC samples.

2) Increase the compressive strength of RPC from 75 to $90 \mathrm{MPa}$, increases the shear strength by $25 \%$. This confirms the major role of concrete compressive strength on strength of the shear.

3) Increment in the contents of steel fiber starting with $0 \%$ to $1.5 \%$ against an increment in strength of the shear up to $261 \%$. This confirms that steel fiber affects the principal strength of tensile which accordingly increases the shear strength.

4) Existence of transverse steel bar in the direction of shear line provides an increment in strength of the shear up to $108.3 \%$. This confirms the major role of steel bar in increasing the shear strength compared without steel bar.

5) A presence of small aggregate in constructing RPC specimen leads to increase the shear strength by $9.1 \%$. This is due aggregate interlock effect. 
TABLE VI: Shear strength of push-off specimens

\begin{tabular}{cccccc}
\hline \hline Specimen mark & Conc & Steel fiber & Splitting tensile & Compressive & Ultimate \\
\hline L1-Ref & RPC & 0.5 & 4.0 & 90 & 120 \\
L2 - NSC-NSC & NC & --- & 2.7 & 35 & 81 \\
L3 - fc80 & RPC & 0.5 & 3.2 & 75 & 96 \\
L4 - 0\%fib & RPC & 0 & 1.8 & 87 & 54 \\
L5 - 1\%fib & RPC & 1.0 & 5.0 & 98 & 150 \\
L6 - 1.5\%fib & RPC & 1.5 & 6.5 & 105 & 195 \\
L7 - Rein & RPC & 0.5 & 4.0 & 90 & 250 \\
L8 -agg5mm & RPC & 0.5 & 4.1 & 93 & 131 \\
\hline
\end{tabular}

\section{Shear stress - slip and Shear stress-crack width behavior}

As previously pointed, the shear stress is calculated by dividing the applied load on the shear plane area. Meanwhile, the vertical displacement (shear slip) is reordered through the dial gauge installed at the top of the specimen. The lateral displacement (crack width) is recorded through the dial gage installed at the middle of the specimen. Figures 2 through 16 represent the shear stress-slip behavior and shear stress-crack width behavior. Both behaviors show approximately linear relation till the failure which confirms the brittle behavior in shear failure. These two behaviors show the following points:

- The presence of lateral reinforcement in the shear plane decreases the slip and lateral displacement by $100 \%$.

- Increment in compressive strength from $35 \mathrm{MPa}$ to $120 \mathrm{MPa}$, decrease the slip and lateral displacement by $50 \%$.

- Increment in steel fiber content beginning with $0 \%$ to $1.5 \%$ decrease the slip and lateral displacement by $300 \%$.

- Adding of small size of aggregate to RPC decrease the slip and lateral displacement by $10 \%$.

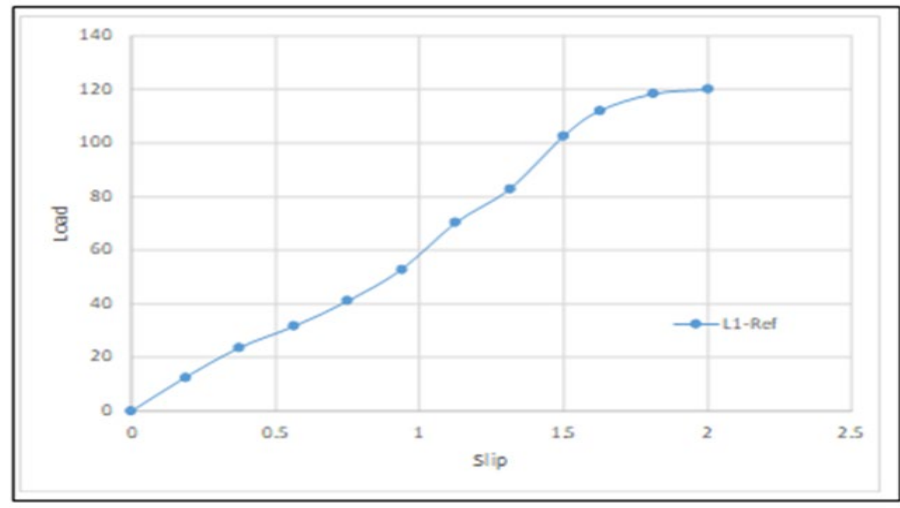

Figure 3: Load - slip for specimen L1 - Ref

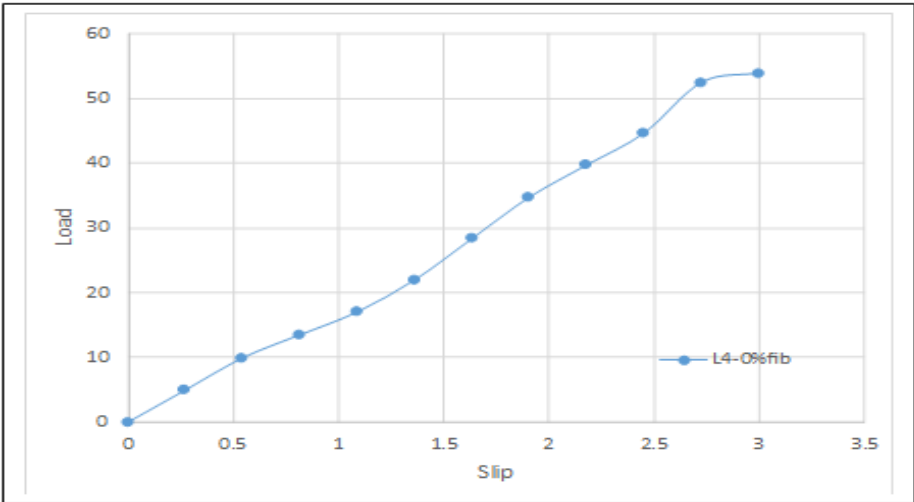

Figure 4: Load - slip for specimen L4 - 0\%fib 


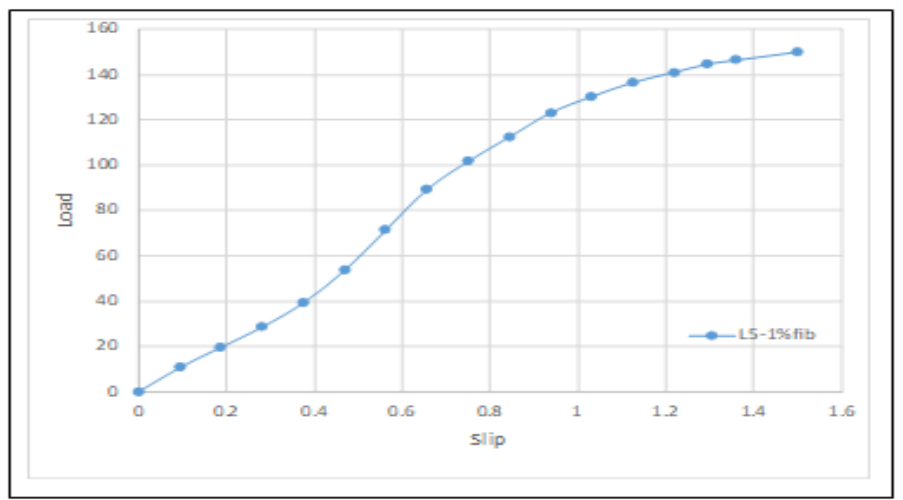

Figure 5: Load - slip for specimen L5 - 1\%fib

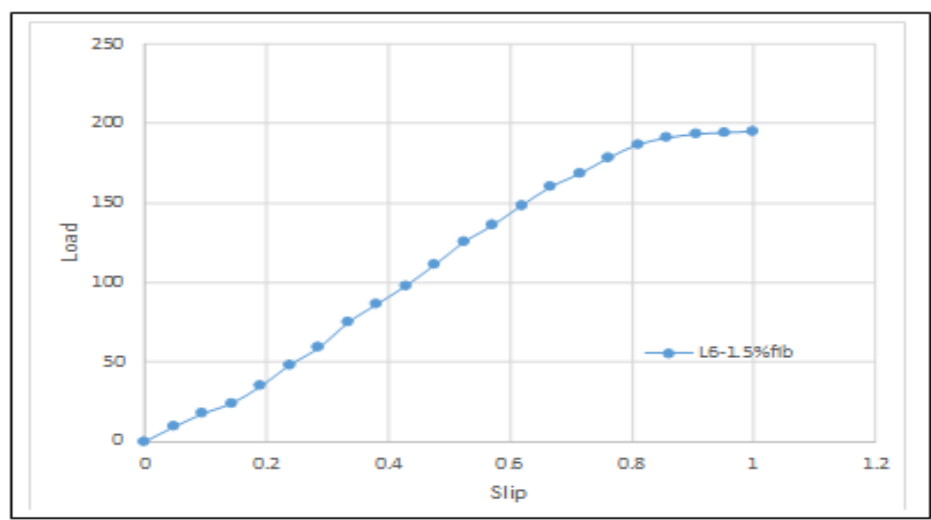

Figure 6: Load - slip for specimen L6 - 1.5\% fib

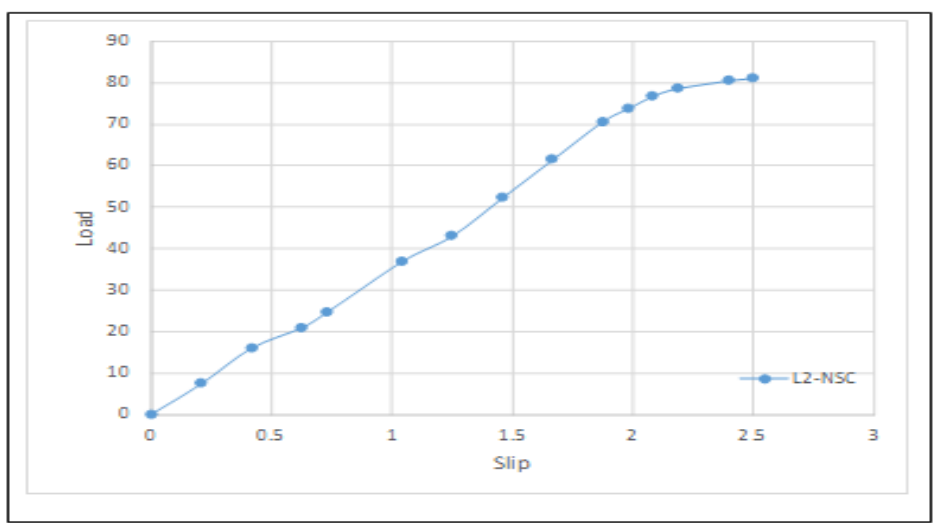

Figure 7: Load - slip for specimen L2 - NSC - NSC

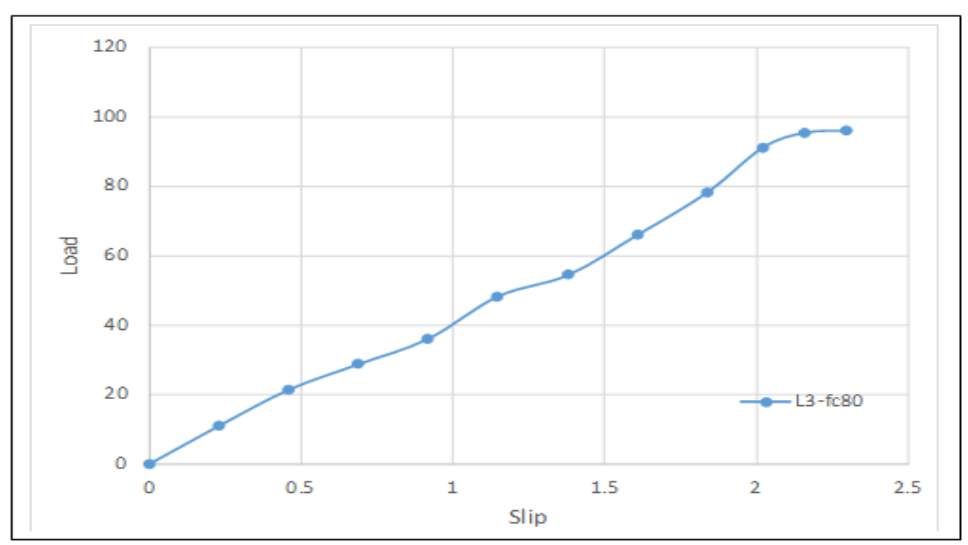

Figure 8: Load - slip for specimen L3 - Fc80 


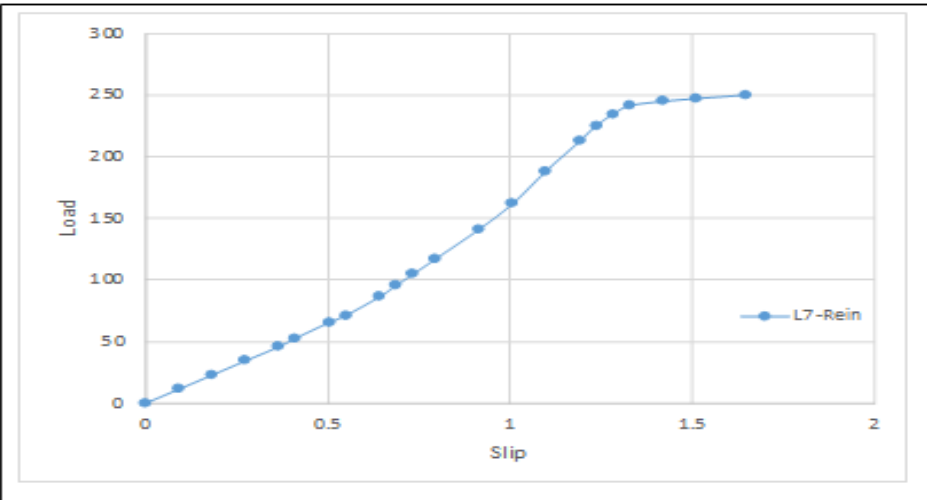

Figure 9: Load - slip for specimen L7 - Rein

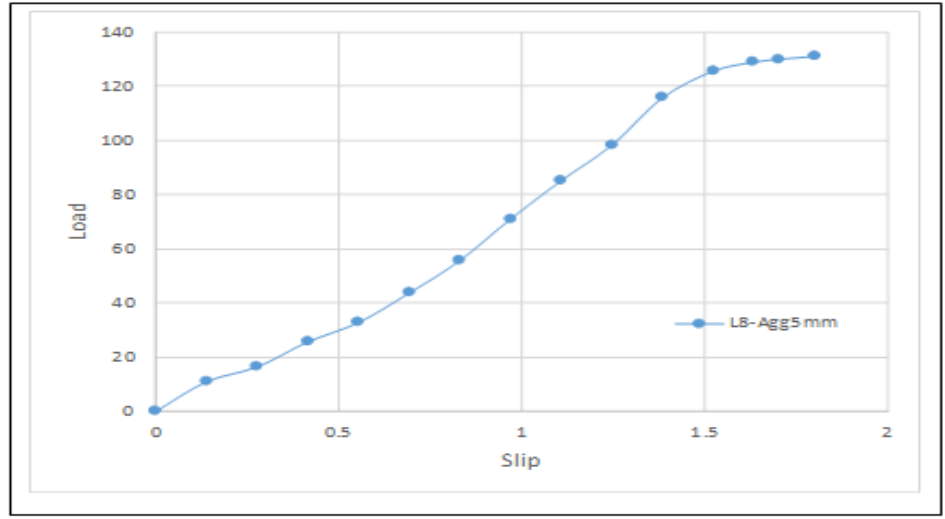

Figure 10: Load - slip for specimen L8 - Agg5mm

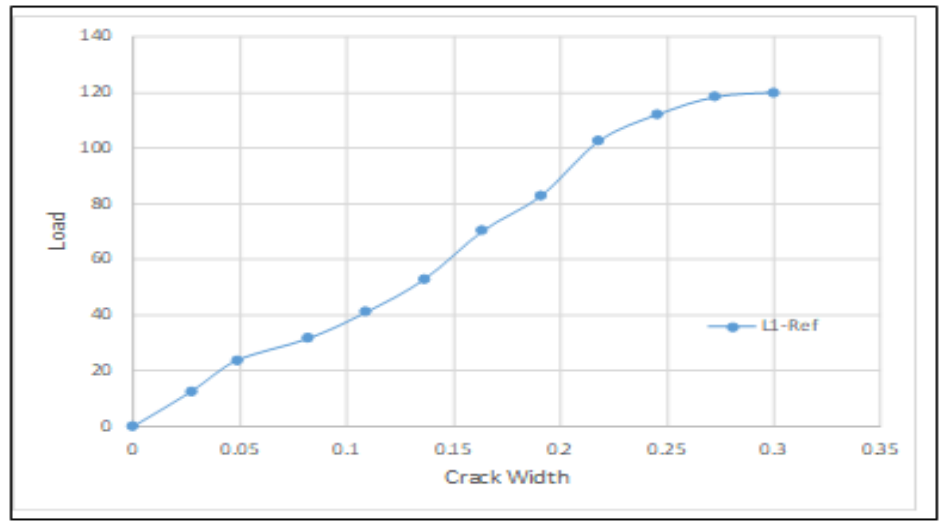

Figure 11: Load - crack width for specimen L1- Ref

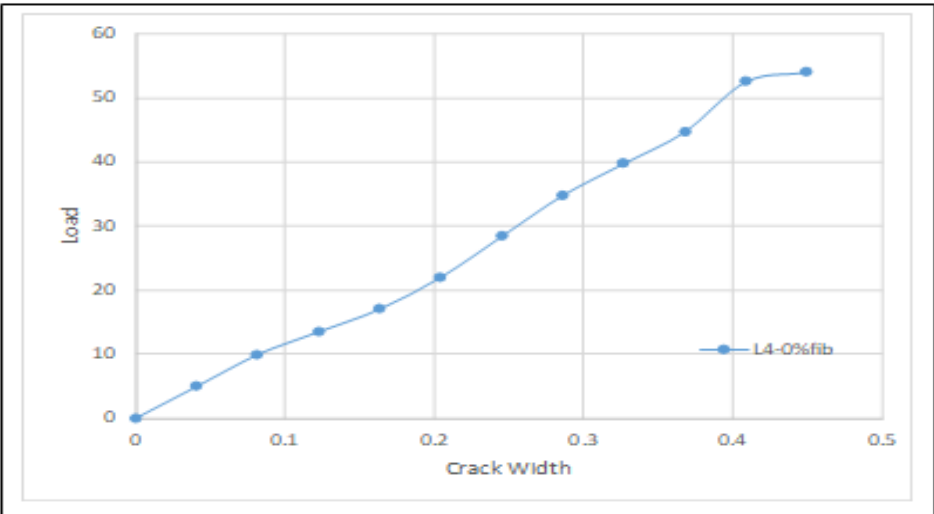

Figure 12: Load - crack width for specimen L4 - 0\% fib 


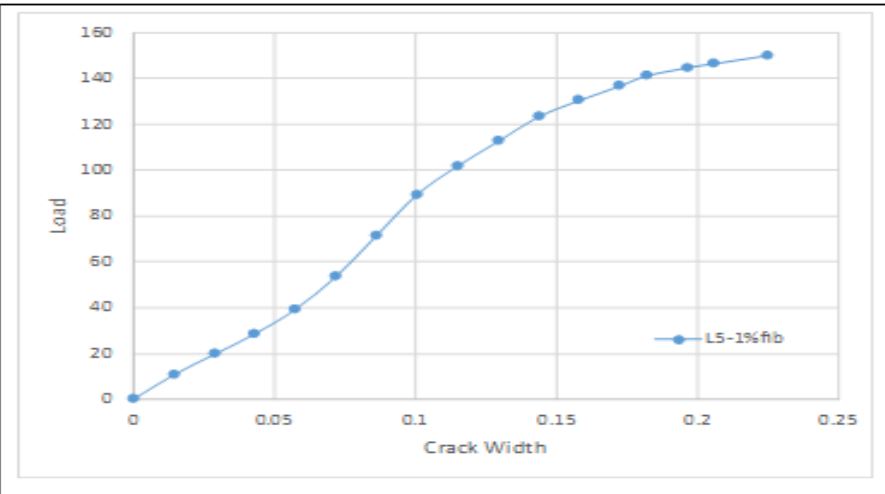

Figure 13: Load - crack width for specimen L5 - 1\%fib

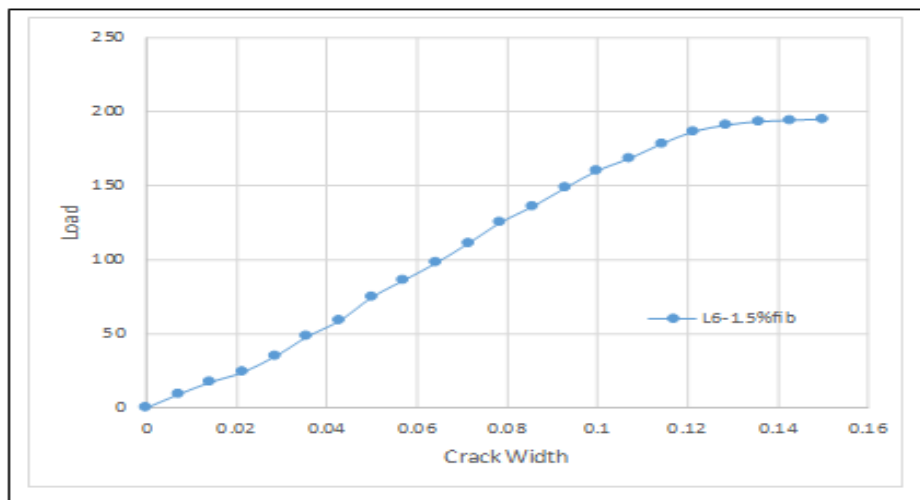

Figure 14: Load crack width for specimen L6 - 1.5\% fib.

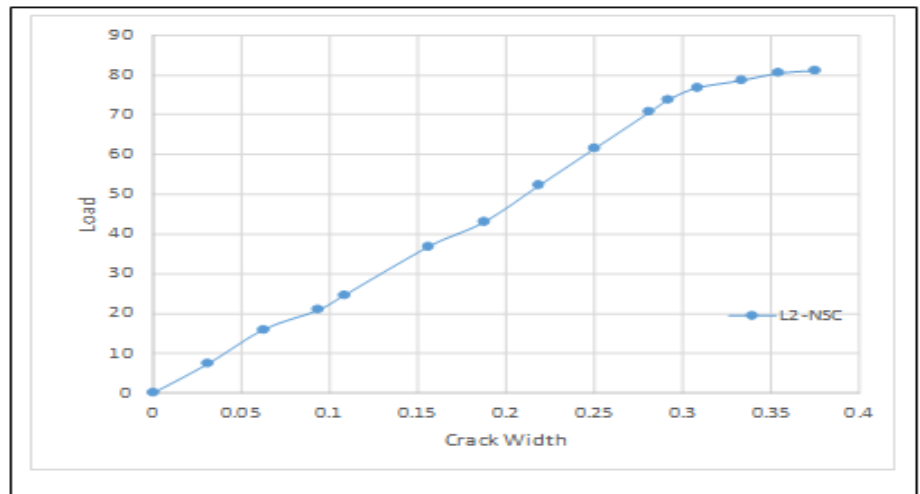

Figure 15: Load - crack width for specimen L2 - NSC

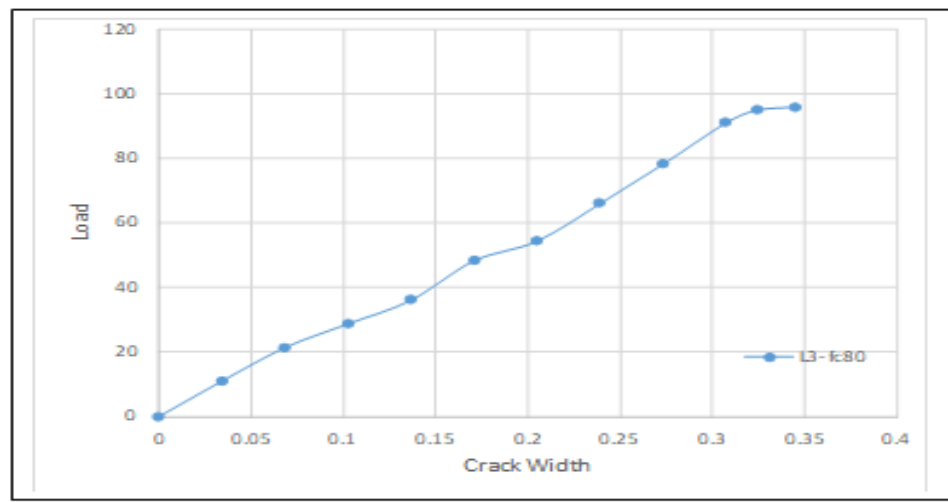

Figure 16: Load - crack width for specimen L3 - FC80 


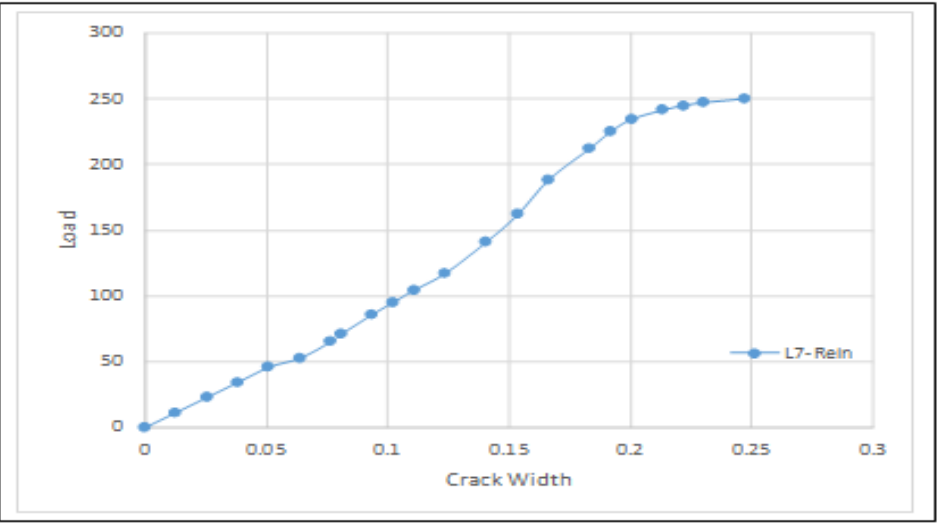

Figure 17: Load - crack width for specimen L7 - Rein

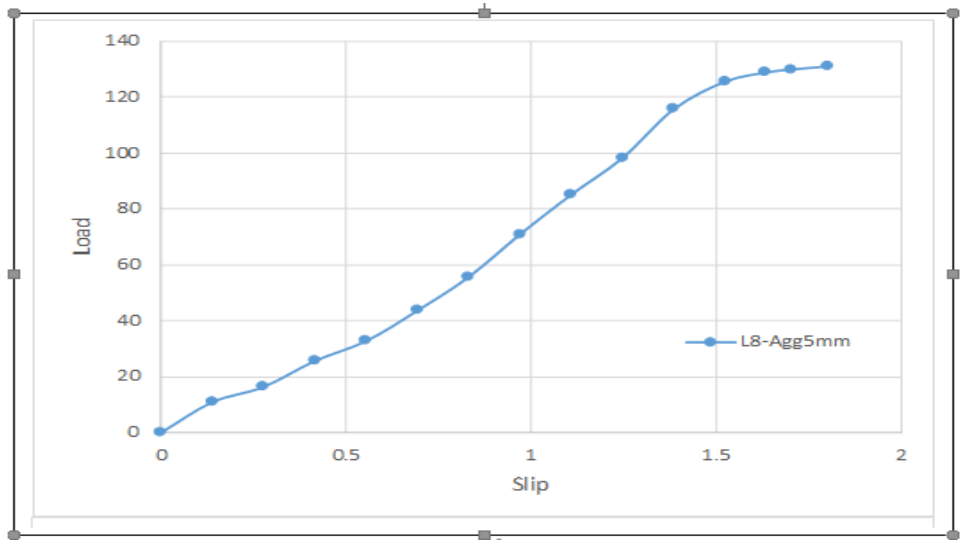

Figure 18: Load - crack width for specimen L8 - Agg5mm

\section{MODES OF FAILURE}

Crack is one of the modes of failure beginning close to the line separating between two L blokes (at shear plane) for both NC and RPC. Figure 18 represent the direct shear measurement, the flexural cracks was not represented by horizontal arms regarding the samples of push off which related to the adequate bars for reinforcing which where putted for shear cracks resistance that is usually progressed along the interface between mortar and coarse aggregate. At the surface, and due to defamation from the shear, aggregate interlock will develop which is the frictional force that represents the concrete shear strength.

For the RPC in the unit volume there are no coarse aggregates was utilize and the existence of the steel fiber had the controlling part of shear transfer ability. Suddenly, the push-off samples failed with a loud sound because the brittle way of failure

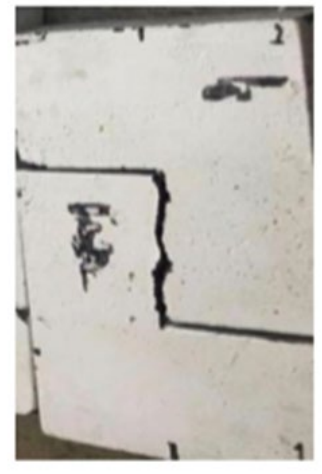

a ( Ll-REF)

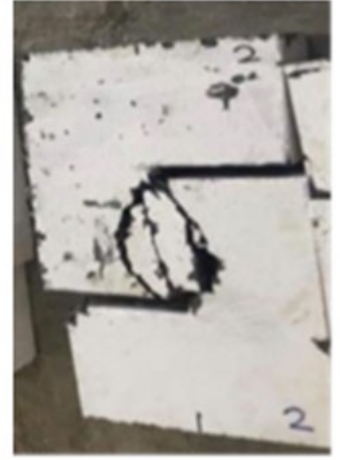

b (L3-fc80) 


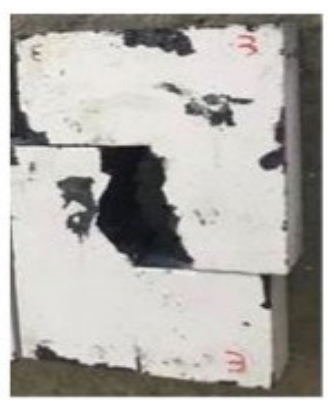

C ( L4-0\%fib)

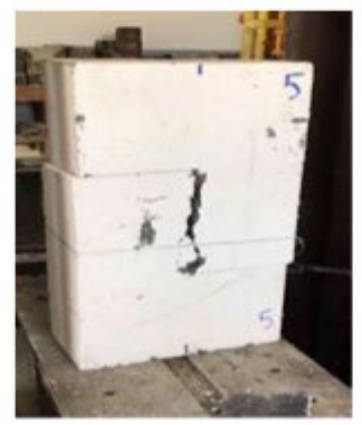

e ( L6-1.5\% fib)

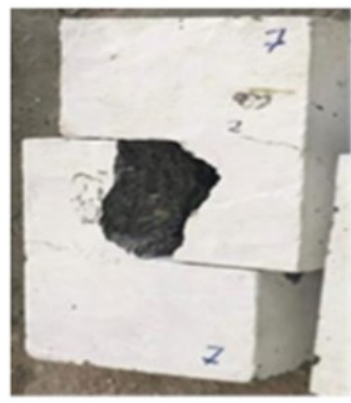

g ( L2-NSC)

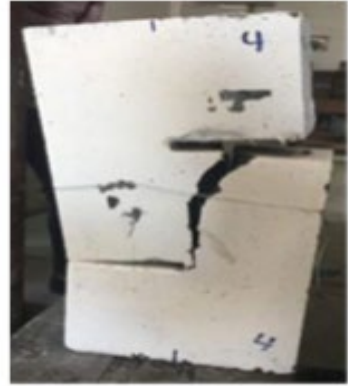

d (L5-1\%fib)

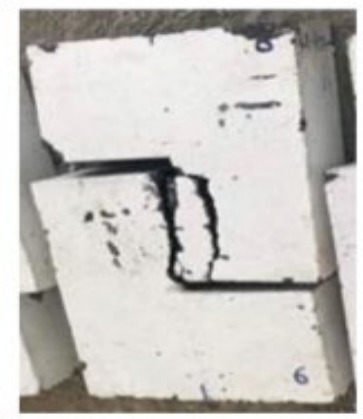

f (L8-Agg $5 \mathrm{~mm})$

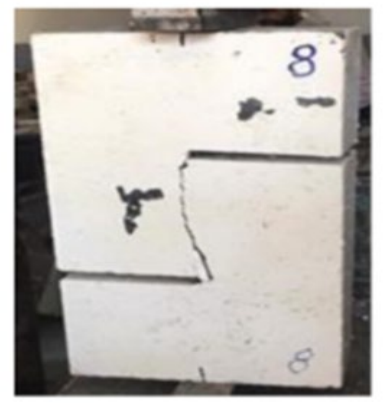

h ( L7-Rein)

Figure 19: Failure mode for all specimens.

\section{CONCLUSIONS}

1) The shear strength of concrete is increased by $29.6 \%$ when the specimen constructed from RPC compared with the NSC.

2) The compressive strength of RPC increase from 75 to $90 \mathrm{MPa}$ increases the shear strength by $25 \%$.

3) Increase in the steel fiber content from (0 to $1.5 \%)$ leads to increase in the shear strength by (261\%) compare with specimen without steel fibers.

4) The presence of transverse steel rebar in the direction of shear line increased the shear strength by (108.3\%) as compare with the specimen without shear rebar.

5) The presence of small aggregate in RPC mixed leads to increase in the shear strength by $(9.1 \%)$.

6) The presence of lateral reinforcement in the shear plane decreases the slip and lateral displacement by $(100 \%)$.

7) Increase the concrete compressive strength from 35 to $120 \mathrm{MPa}$, decrease the slip and lateral displacement by $(50 \%)$.

8) Increase the steel fiber content from (0 to $1.5 \%)$ decrease the slip and lateral displacement by $(300 \%)$. 
9) Adding of small size of aggregate to RPC decrease the slip and lateral displacement by $(10 \%)$.

\section{REFRENCES}

[1] P. Birkeland and H. Birkeland, Connections in precast concrete construction, ACI journal, 63. 345-368. carried by steel fibers of reinforced concrete beams using tension softening curves, Int. J. Concr. Struct. Mater., 67(1966) 507- 493.

[2] P. Jongvivatsakul, K. Watanabe, K. Matsumoto and J. Niwa, Shear capacity of fiber reinforced concrete beams with various types and combinations of fibers, Journal. JSCE., 2011.

[3] P. Richard, and M. Cheyrezy, Composition of reactive powder concrete, Cem. Concr. Res., 25(1995) 1501 -11. https://doi.org/10.1016/0008-8846(95)00144-2

[4] D. B. Ghailan, Shear-Transfer Strength And Behavior of Reactive Powder Concrete, Ph.D. Thesis., 2013.

[5] S. P. Y. Hannawayya, Behavior Of Reactive Powder Concrete Beams in Bending, Ph.D. Thesis., 2010

[6] L. S. Danha, Tensile Behavior Of Reactive Powder Concrete, M.Sc. Thesis., 2012.

[7] Central Organization for Standardization and Quality Control. Iraqi Standard Specification (IQS). Ordinary Portland cement, No.5/1984, Baghdad, Iraq. (1984).

[8] ASTM-A820-04, Standard Specification for Steel Fibers for Fiber-Reinforced Concrete, American Society of Testing and Materials, 2004. 